\title{
Who Adopts Agroforestry in a Subsistence Economy?
}

\author{
Arun Dhakal ${ }^{1}$, and Rajesh Kumar Rai ${ }^{2, *}$ \\ 1 Nepal Agroforestry Foundation (NAF), Kathmandu, Nepal \\ 2 The Center for People and Forests (RECOFTC), Bangkok, Thailand \\ * Correspondence: rjerung@gmail.com
}

\begin{abstract}
Land degradation is a critical issue globally putting our future generations at risk. The decrease in farm productivity over the years is evidence of land degradation severity in Nepal. Among the many strategies in place, agroforestry, which is an integrated tree-based farming, is widely recommended to address this productivity issue. This paper thoroughly examines what influences the choice of agroforestry adoption by farmers and what discourages the adoption. For this, a total of 288 households were surveyed using a structured questionnaire. Two agroforestry practices were compared with conventional agriculture with the help of the Multinomial Logistic Regression (MNL) model. The likelihood of adoption was found to be influenced by gender; the male-headed households were more likely to adopt the tree-based farming practice. Having a source of off-farm income was positively associated with the adoption decision of farmers. Area of farmland was found being the major constraint to agroforestry adoption for smallholder farmers. Some other variables that affected positively included livestock herd size, provision of extension service, home-to- forest distance, farmers' group membership and awareness of farmers about environmental benefits of agroforestry. Irrigation was another adoption constraint that the study area farmers were faced with. The households with means of transport and with larger family (household) size were found to be reluctant towards agroforestry adoption. A collective farming practice could be a strategy to engage the smallholder farmers in agroforestry.
\end{abstract}

Keywords: conventional agriculture; land degradation; small-holders; multinomial logistic regression; Nepal 


\section{Introduction}

Land degradation, a persistent decline in soil quality and its productivity caused by natural or anthropogenic factors, has adversely affected food production, the supply of ecosystem services and livelihoods globally [1]. Even though it occurs throughout the world, the extent and degree of degradation vary with regions. For instance, dryland areas of African countries and Australia; mountain ranges of the Himalayas; and densely populated areas of South Asia are more vulnerable $[2,3]$. The consequences of land degradation are severe as it impacts adversely on farm-productivity, and hence, on food security [4]. By 2030, the demand for food is expected to increase by at least $50 \%$, which requires conservation and restoration of the productivity of agricultural land. It is estimated that a $60 \%$ increase in agricultural productivity, will be necessary by 2050 in order to overcome hunger and food insecurity [5].

Many factors are responsible for the global spread of agricultural land degradation. The spread and growth of populations, inappropriate land-use practices, excessive use of chemicals, mechanized agriculture and natural phenomena such as erosion, floods and drought are the proximate causes of degradation [4]. In countries like Nepal, where the demographic pattern is changing substantially due to the outmigration of the economically active population, agriculture land degradation is becoming a serious issue [6]. In a subsistence economy, farmers are forced to cultivate marginal lands; use agrochemicals; and follow intensive farming and mechanized agriculture to sustain their livelihoods. All these activities have supported a gradual decline in soil fertility $[7,8]$.

Reducing further degradation and restoring the degraded agricultural land may contribute to the first three sustainable development goals (SDGs) including no poverty; and good health and well-being substantially. Since the underlying causes of land degradation are multifaceted, it requires an integrated approach of farmland management [4]. A single strategy may be counterproductive, for instance, reduction in chemical fertilizer application may result in decreased crop yield and hence, food insecurity. In this context, agroforestry, which is an integrated tree-based farming system, has come into the forefront given the potential to address land degradation with additional environmental and social benefits $[9,10]$. Agroforestry supports biodiversity conservation [11-14]. Similarly, it has higher financial returns compared to that of the conventional agriculture [15]. It also provides biosafety as it is less likely to have crop failure compared to the treeless system [16]. This may be because the agroforestry system restores soil fertility [15,17] and rehabilitates degraded agricultural land [18].

Having so many economic and environmental benefits, agroforestry should be a widely adopted practice. However, the adoption status of such promising land use is not encouraging and not widespread as expected even though there are several national and international organizations working in the promotion of this agricultural practice. There might be disincentives to establishing trees including lack of knowledge, upfront costs, length of time until there is a return and a short to medium-term reduction in cash flow and/or household food production [19]. Nonetheless, there has been a wealth of research works on agroforestry adoption [20]. Most of the existing literature is focused on the socio-economic, and environmental contributions of an agroforestry system (21-23).

However, the main question to be answered is what the determinants of adopting an agroforestry system are. This study assesses the determining factors of agroforestry adoption in 
Nepal. The findings of the study are useful for policymakers, development agencies and academicians.

\section{Materials and Methods}

\subsection{Study area and descriptions}

Dhanusha district, which is in the southern part of Nepal and shares a border with India, was selected for this study. About $60 \%$ of the land comes under agriculture out of the total area of the district, 119000 ha. Data were collected from May through August 2014. Like other parts of Nepal, agriculture is the major economy of the district where about $90 \%$ of people are actively engaged in the cultivation of wheat, rice, and sugarcane [24]. After the state federalization, the district now falls in the province no. 2. Located approximately $95 \mathrm{~m}$ above the sea level, the district is one of the hottest districts of Nepal with the average annual rainfall being $2199 \mathrm{~mm}$. The meteorological data shows that April is the warmest month with the average temperature being $39.60 \mathrm{C}$ (maximum) while January is the coldest with the average temperature of $21.40 \mathrm{C}$ (maximum) [25].

Administratively the district consists of one sub-metropolitan city, eleven urban municipalities and six rural municipalities. The Terai Private Forest Development Association (TPFDA), a local NGO, has worked to promote a tree-based farming practice in then nine Village Development Committees (VDCs ${ }^{1}$ ) covering 10,500 hectares (Figure 1). Therefore, these nine VDCs were selected as the study site. After the state is restructured, some parts of the study site fall in the urban municipality while most parts are still VDCs, now known as rural municipalities.

${ }^{1}$ Now, VDCs are a part of either urban or rural municipalities after restructuring the state. 


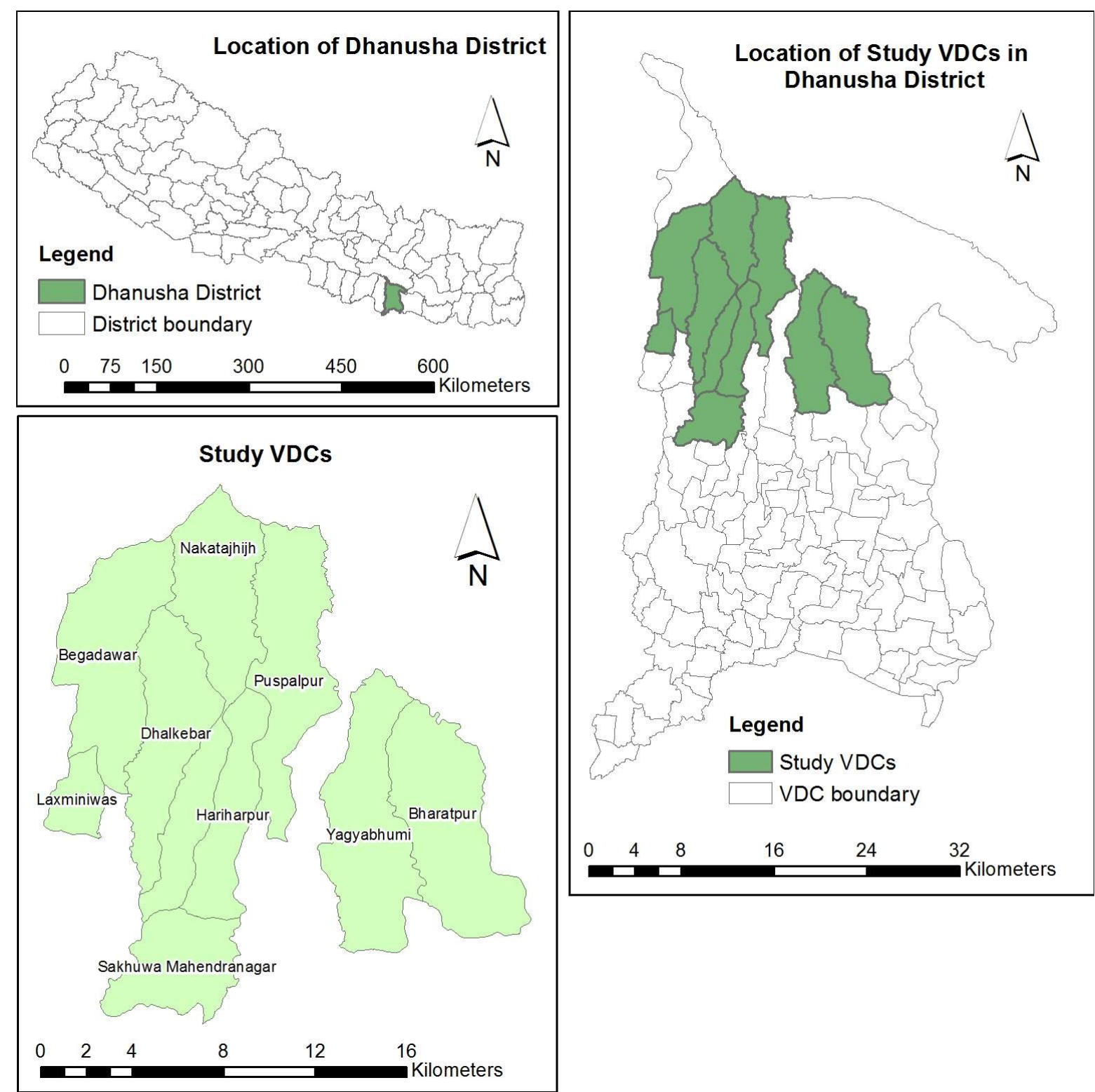

Figure 1. Study area

\subsection{Household survey}

A two-stage sampling approach was adopted for this study. First, one ward ${ }^{2}$ from each VDC was selected through purposive sampling. This means a total of nine wards were selected. Second, thirty-two households from each ward were selected randomly. This means 288 sample households were selected. In-person interviews were conducted with the head of the sample households using a structured questionnaire.

The questionnaire covered the household data- the demography and socio-economic conditions of the sampled households. Also included in the questionnaire were the institutional and biophysical variables which we hypothesized as adoption determinants and constraints. A total of 18 households were dropped out of the analysis since these households were practicing a combination of two or more agroforestry practices, agroforest/woodlot, boundary plantation and alley cropping.

\footnotetext{
${ }^{2}$ Ward is the lowest administrative unit.
} 


\subsection{Analytical model}

Logistic regression model is the best fit when the outcome (dependent) variables are unordered and categorical. When there are only two outcome variables, the binary choice model (binary regression model) is the best fit. In our case, the outcome variable is different types of farming practices adopted by the study area farmers. Since we have more than two farming practices i.e. (i) agroforest/woodlot system (AFS), (ii) alley cropping system (ACS), (iii) combination of two or more AF practices, and (iv) conventional agricultural system (CAS), the binary choice model is not suitable. Out of the four practices, the third practice was dropped off from the analysis since the practice was very rarely practiced in the study area. Since we still have more than two practices even after dropping one practice off, we chose Multinomial Regression Model (MRM) for our analysis. Most commonly used multinomial regression models are probit model and logit model. We chose the Multinomial logit (MNL) model for our study since it gives more precise parameter estimation [26]. The MNL model estimates the likelihood of adoption of non-reference categories against a reference (base) category in terms of relative risk ratio (RRR) [27]. The other reason for choosing this model is that this has been more commonly used in recent studies [27-30]. Having three farming practices in place, farmers can choose the one they prefer the most from the three alternatives. That means their choice is mutually exclusive.

We assumed farmers follow the random utility theory, while making the choice out of the three farming practices available. Therefore, we used a random utility model while determining the farmers' choice of farming practices, as given by Greene [31].

$$
Y_{i j}=\beta_{j} X_{i j}+\varepsilon_{i j}
$$

where Yij denotes the utility of farmer i obtained from farming choice $\mathrm{j}$, $\mathrm{Xij}_{\mathrm{ij}}$ denotes all the factors affecting farmers' decision to adopt a farming practice $j$ and $\beta \mathrm{j}$ is the parameter that reflects changes on Yij due to changes in $\mathrm{Xij}$. We assumed the error terms to have an independent and identical distribution (iid) [32]. According to profit maximization, farmer i will, thus, only choose a specific alternative $\mathrm{j}$ if $Y \mathrm{ij}>\mathrm{Yik}$ for all $\mathrm{k} \neq \mathrm{j}$. This choice of $\mathrm{j}$ depends on a number of predictor (independent) variables as denoted by $\mathrm{X}_{\mathrm{ij}}$ in the above equation. If $\mathrm{Yi}_{\mathrm{i}}$ is a random choice that a farmer can make, the MNL model can be expressed as:

$$
\operatorname{Prob}(Y i=j)=\frac{e^{\beta_{j} x_{i}}}{\sum_{j=1}^{j} e^{\beta_{j} x_{i}}}
$$

$$
j=0,1,2, \ldots \ldots, j
$$

The above equation estimates probabilities for $\mathrm{j}+1$ farming choices i.e. three practices for farmers with a number of independent variables, $\mathrm{Xij}$. Here, we are to estimate the probabilities of two non-reference farming practices, agroforest system and Alley cropping system against the reference category i.e. conventional agriculture and this can be done by assuming $\beta 0=0$ and expressed as follows:

$$
\begin{gathered}
\operatorname{Prob}(Y i=j)=\frac{e^{\beta_{j} x_{i}}}{1+\sum_{j=1}^{j} e^{\beta_{j} x_{i}}} \\
\operatorname{Prob}(Y i=0)=\frac{e^{\beta_{j} x_{i}}}{1+\sum_{j=1}^{j} e^{\beta_{j} x_{i}}} \ldots \ldots
\end{gathered}
$$




\subsection{Variables defined}

The dependent variable is the adoption of farming practices by farmers as denoted by Yi. For MNL model, the outcome (dependent) variable was denoted as:

$\mathrm{Yi}=0$ if a household adopts conventional agriculture system (CAS) -reference category- $(j=0)$;

$\mathrm{Yi}=1$ if a household adopts agroforest system (AFS)- non-reference category- $(j=1)$;

$\mathrm{Yi}=2$ if a household adopts alley cropping system (ACS)- non-reference category- $(\mathrm{j}=2)$.

Before the model is run, all the hypothesized independent variables were tested for multicollinearity using the variance inflation factor (VIF). We found the VIFs of the independent variables being than 10 (1.09-2.03), indicating there is no issue of multicollinearity.

The estimation of the MNL model for this study was undertaken by selecting CAS as the base category. The odds of two other farming systems namely AFS and ACS against the CAS were estimated in this study. Since the CAS was the base category, it was hypothesized that most predictor variables will positively impact the adoption of the tree-based farming practices i.e. one unit increase in an " independent variable will increase the likelihood of AFS and ACS adoption.

\subsection{Variables used in the model}

The three farming practices were the dependent variables out of which farmers chose the one they preferred the most. We extensively reviewed the contemporary literature on adoption to identify and determine independent (explanatory) variables. The explanatory variables included socio-economic, biophysical and institutional characteristics (Table 1). However, some variables were excluded in the model. The variable 'farmers' perception on agroforestry' was dropped off the model because studies suggest it had no relationship with adoption [33-36] and also the methodological challenge we faced to precisely measure the perception made us drop this variable off the model [37]. The 'slope gradient' is another variable we ignored because of little altitudinal variation across the sampled households. The third variable 'access to credit facility' was also excluded because of no financial guarantee from the financial institutions for agroforestry promotion in the study area. 
Table 1. Description of the explanatory variables specified in the multinomial logistic model

\begin{tabular}{|c|c|c|c|}
\hline Variables & Description & Type of measure & Expected sign \\
\hline Education & $\begin{array}{l}\text { Years of formal education of household } \\
\text { head }\end{array}$ & Years & + \\
\hline Age & Age of the household head & Years & - \\
\hline Sex & Sex of the household head & $\begin{array}{l}1 \text { if male, } 0 \\
\text { otherwise }\end{array}$ & + \\
\hline Household size & $\begin{array}{l}\text { Number of family members between } 15 \\
\text { to } 60 \text { years }\end{array}$ & Years & - \\
\hline Off-farm income & $\begin{array}{l}\text { Farmer has any off-farm source of } \\
\text { income }\end{array}$ & 1 if yes, 0 otherwise & + \\
\hline Landholding size & Total cultivated area & Katha* & + \\
\hline Livestock herd size & $\begin{array}{l}\text { Total number of cattle and buffaloes } \\
\text { kept by a surveyed household }\end{array}$ & Numbers & + \\
\hline Extension service & $\begin{array}{l}\text { Total number of training received and } \\
\text { visits by extension workers in the last } \\
\text { five years }\end{array}$ & Numbers & + \\
\hline HF_distance & $\begin{array}{l}\text { Distance from home to nearest } \\
\text { government forest }\end{array}$ & Kilometres & + \\
\hline Transport & $\begin{array}{l}\text { Means of transport possessed by the } \\
\text { surveyed household }\end{array}$ & $\begin{array}{l}1 \text { if a farmer has } \\
\text { own means of } \\
\text { transport, } \\
\text { otherwise }\end{array}$ &,+- \\
\hline Irrigation facility & Farm has any source of irrigation & 1 if yes, 0 otherwise & + \\
\hline Membership & $\begin{array}{l}\text { Member of farmers' group and } \\
\text { organization }\end{array}$ & 1 if yes, 0 otherwise & + \\
\hline Origin & Farmer is native & 1 if yes, 0 otherwise & + \\
\hline Risk taking attitude & $\begin{array}{l}\text { Farmer is risk-averse, risk-neutral and } \\
\text { risk loving }\end{array}$ & $\begin{array}{l}1 \text { if risk loving, } 2 \text { if } \\
\text { risk-neutral and } 3 \\
\text { if risk-averse }\end{array}$ & + \\
\hline Awareness & $\begin{array}{l}\text { Farmer is aware of environmental } \\
\text { benefits of an agroforestry practice }\end{array}$ & 1 if yes, 0 otherwise & + \\
\hline
\end{tabular}

\section{Results}

\subsection{Sample characteristics}

The average age of the sampled household heads was 44 years. Younger farmers were practicing agroforestry system and AFS farmers were the youngest (Table 2). In addition, 15\% of household heads were illiterate. They were the large households with seven family members on average, nearly 1.5 times larger than the average national family size, which is 4.9 people per family [25]. The sample households are dominated by the male heads (57\%), out of which $65 \%$ male heads 
were in the AFS adopting households and 55\% male heads in both ACS and CAS adopting households. Most respondents (54\%) were solely rely on farm income and the rest $46 \%$ had both off-farm and on-farm sources of income.

The results indicated that $44 \%$ of the sample households had access to irrigation. Of them, $62 \%$ of the total AFS farmers had access to the irrigation facility while only $46 \%$ and $35 \%$ of the farmers adopting ACS and CAS respectively possessed this facility. Many of these farmers (56\%) were migrated from Nepal's hilly region and India to the study area. However, 58\% of farmers, who were in the AFS group were native, while there were only $40 \%$ and $41 \%$ native farmers in ACS and CAS respectively. Out of eleven variables (continuous) tested, five variables i.e. education, landholding size, livestock herd size, extension service, and availability of transport means are significantly different in their mean values (Table 2). The mean values of three variables i.e. household head's age, household size (economically active) and crop diversity were significantly different for CAS and ACS. The statistics suggest that the households with large holdings and bigger livestock herd size that are headed by a young and educated male family member receiving more extension services tend to adopt the tree-based farming (Table 2).

Table 2. Characteristics of sample households in the study area

\begin{tabular}{llll}
\hline Variables & \multicolumn{3}{l}{ Mean values of the variables } \\
\cline { 2 - 4 } & CAS $(\mathbf{n}=\mathbf{1 6 2})$ & ACS $(\mathbf{n}=\mathbf{6 0})$ & AFS (n = 48) \\
\hline Years of schooling (Education) & $5.0(3.6)^{\mathrm{a}}$ & $6.3(3.7)^{\mathrm{b}}$ & $9.6(4.0)^{\mathrm{c}}$ \\
Age of household head & $46.6(13.2)^{\mathrm{a}}$ & $43.6(9.9)$ & $39.4(10.0)^{\mathrm{b}}$ \\
Sex of household head & $0.55(0.50)$ & $0.56(0.50)$ & $0.64(0.48)$ \\
Household size & $4.7(2.1)^{\mathrm{a}}$ & $4.4(1.9)$ & $3.9(1.3)^{\mathrm{b}}$ \\
Off-farm income & $0.32(0.50)$ & $0.49(0.50)$ & $0.75(0.43)$ \\
Landholding size & $23.8(21.1)^{\mathrm{a}}$ & $34.7(25.4)^{\mathrm{b}}$ & $74.3(36.7)^{\mathrm{c}}$ \\
Livestock herd size & $2.9(1.9)^{\mathrm{a}}$ & $3.7(2.6)^{\mathrm{b}}$ & $6.7(2.8)^{\mathrm{c}}$ \\
Extension service & $0.80(1.1)^{\mathrm{a}}$ & $3.2(2.2)^{\mathrm{b}}$ & $5.5(1.7)^{\mathrm{c}}$ \\
Distance from home to nearest government & $4.2(2.7)^{\mathrm{a}}$ & $9.0(5.6)^{\mathrm{b}}$ & $9.3(5.5)^{\mathrm{b}}$ \\
forest & & & \\
Transport (tractor, bullock cart) & $0.6(0.51)$ & $0.4(0.51)$ & $0.3(0.48)$ \\
Irrigation & $0.35(0.48)$ & $0.46(0.50)$ & $0.63(0.49)$ \\
Membership & $0.25(0.43)$ & $0.51(0.50)$ & $0.73(0.45)$ \\
Origin & $0.41(0.49)$ & $0.40(0.49)$ & $0.58(0.50)$ \\
Risk taking attitude & $2.4(0.80)$ & $1.71(0.77)$ & $1.52(0.74)$ \\
Awareness & $0.28(0.45)$ & $0.51(0.50)$ & $0.69(0.47)$ \\
Tree density (no of trees/hectare) & 0 & $101(38)^{\mathrm{a}}$ & $245(49)^{\mathrm{b}}$ \\
No. of agricultural crops grown in a year & $7.0(2.0)^{\mathrm{a}}$ & $8.0(2.0)$ & $10.0(3.0)^{\mathrm{b}}$ \\
\hline
\end{tabular}

Note: Figure in the parenthesis is the standard deviation. Means in a row with different superscripts are significant at 0.05 level. CAS: Conventional agricultural system; ACS: Alley cropping system and AFS: Agroforest system 
3.2. Association, relative risk and significance of explanatory variables with regards to the choice of farming systems

The parameter estimates (association) and relative risk ratios (RRR) of the MNL model for AFS and ACS with CAS as a reference group are reported in Table 3. The coefficients show the direction of explanatory variables, while the RRR shows the likelihood of adoption/dis-adoption of AFS and ACS by farmers with respect to CAS. The model was significant at the $1 \%$ level. The log-likelihood ratio (LR) test helps to identify the best models between two competing models. In this analysis, it is expected the significant relationship between likelihood of adoption behavior and the selected independent variables. This test suggests the effects of independent variables as a group, rather than individual, even some variables and RRR were not significant individually.

All other variables had expected signs except for the two variables, 'irrigation facility' and 'origin'. The variable 'irrigation facility' is positive and has a significant relationship with the adoption of AFS and ACS but it is not significant in the case of ACS. The variable 'Origin' had a negative sign in the case of ACS suggesting that a migrated farmer is more likely to prefer ACS to CAS. Out of fifteen variables tested, twelve variables were significant in the case of AFS while there were only five variables significantly affecting the adoption of ACS. Our result suggests that the likelihood of adopting AFS would increase by a unit of 1.323 if the household head were a male. Similarly, the AFS was 2.9 times more likely to be adopted by households having off-farm income sources. Having a private source of irrigation would increase the likelihood of AFS adoption by 1.73.

There are some variables with negative signs indicating that these variables decreased the likelihood of adopting AFS and ACS with respect to CAS. If a farmer were risk-averse, the likelihood of adopting AFS would decrease by $89 \%$. In other words, a risk-averse farmer is less likely to adopt an agroforestry system. Similarly, having own source of transport would decrease the likelihood of AFS and ACS adoption by $50 \%$ and $16 \%$ respectively compared to CAS. 
Table 3. Parameter estimates and RRR of a multinomial logistic model for AFS and ACS

\begin{tabular}{|c|c|c|c|c|c|c|}
\hline \multirow[t]{2}{*}{ Variable } & \multicolumn{3}{|l|}{ AFS $(n=48)$} & \multicolumn{3}{|c|}{$\operatorname{ACS}(n=60)$} \\
\hline & Coefficient & RRR & $P$ level & Coefficient & RRR & $P$ level \\
\hline $\begin{array}{l}\text { Years of schooling } \\
\text { (education) }\end{array}$ & 0.159 & 1.172 & 0.247 & 0.114 & 1.121 & 0.194 \\
\hline Age of household head & -0.048 & 0.953 & 0.315 & -0.008 & 1.008 & 0.753 \\
\hline Sex of household head & 1.842 & $1.323^{* *}$ & 0.044 & 0.202 & 0.823 & 0.714 \\
\hline $\begin{array}{l}\text { Working household } \\
\text { members }\end{array}$ & -0.618 & $0.539^{* *}$ & 0.041 & -0.078 & 0.925 & 0.580 \\
\hline Off-farm income & 2.192 & $2.954^{* *}$ & 0.023 & 0.770 & 1.159 & 0.262 \\
\hline Landholding size & 0.123 & $3.130^{* * *+}$ & 0.000 & 0.095 & $1.099^{* * * *}$ & 0.003 \\
\hline Livestock herd size & 0.555 & $1.742^{* * *}$ & 0.003 & 0.178 & 1.195 & 0.179 \\
\hline Extension service & 1.064 & $2.910^{* * * *}$ & 0.000 & 0.529 & $1.697^{* * * *}$ & 0.003 \\
\hline $\begin{array}{l}\text { Distance from home to } \\
\text { government forest }\end{array}$ & 0.376 & $1.457^{* * * *}$ & 0.001 & 0.322 & $1.380^{* * * *}$ & 0.000 \\
\hline Transport & -0.682 & $0.506^{* * *}$ & 0.005 & -0.172 & $0.842^{*}$ & 0.086 \\
\hline Irrigation & 1.907 & $1.732^{* *}$ & 0.042 & 0.302 & 0.352 & 0.571 \\
\hline Membership & 1.831 & $1.242^{* *}$ & 0.038 & 1.349 & $1.122^{* *}$ & 0.019 \\
\hline Origin & 1.215 & 3.371 & 0.188 & -0.336 & 0.714 & 0.551 \\
\hline Risk averse a & -2.134 & $0.118^{* *}$ & 0.041 & -1.208 & 0.299 & 0.123 \\
\hline Risk neutral a & -1.049 & 0.350 & 0.326 & -0.384 & 0.681 & 0.577 \\
\hline Awareness & 1.650 & $1.208^{*}$ & 0.058 & 0.821 & 2.273 & 0.122 \\
\hline Constant & -10.110 & $0.00004^{* * *}$ & 0.004 & -5.213 & $0.0054^{* * *}$ & 0.002 \\
\hline \multicolumn{7}{|l|}{ Diagnostics } \\
\hline Base category & \multicolumn{3}{|c|}{ CAS $(n=162)$} & & & \\
\hline Number of observations & \multicolumn{3}{|l|}{270} & & & \\
\hline LR chi-square & \multicolumn{3}{|l|}{$373.13^{* * *}$} & & & \\
\hline Log likelihood & \multicolumn{3}{|l|}{-93.45} & & & \\
\hline Pseudo R2 & \multicolumn{3}{|l|}{0.67} & & & \\
\hline
\end{tabular}

a risk loving is the reference category. AFS: Agroforest system, ACS: Alley cropping system, CAS: Conventional agricultural system. RRR: Relative risk ratio. ${ }^{*} p<0.10,{ }^{* *} p<0.05$ and ${ }^{* * * *} p<0.01$

\section{Discussion}

The results of the MNL model suggest that twelve variables for AFS and five variables for ACS had significant effects on the adoption decision with respect to CAS. The effects of three variables namely education, age, and origin are statistically insignificant. The negative sign of age of household head suggests that young farmers are more likely to adopt agroforestry systems compared to their elderly neighbors. In other words, the likelihood of adopting an agroforestry system decreases with the increasing age of farmers. This may be because elderly people are more risk-averse compared to the young people; and, therefore, the former expects immediate returns, which is not possible from the tree-based practices [38]. Similarly, education (years of schooling) of farmers have a positive association with the adoption of both AFS and ACS. This is because education may contribute to understand better and adopt a new technology [39]. 
Twelve variables have significant effects in the case of AFS adoption. The sign and $p$ value of the variable 'sex of household head' suggests that male farmers prefer AFS practice compared to their female counterparts. The existing literature also shows that gender differences playing a role in adopting new practices. For example, in studies carried out in Cameroon and Nigeria, it was found that male farmers were more likely to use alley farming than women [38-40]. In Nepalese mid-hills also, a positive association between male-headed households and the adoption of agroforestry practice was found [41]. The sign of the coefficient of the variable 'household size' (economically active) indicates that the likelihood of adopting AFS decreases with the increased household size. In other words, the chance of adopting agroforestry is higher when the household size is relatively low. This holds true because tree-based farming is a less labor-intensive practice in the long-run [19], but other agriculture practices are labor demanding for smallholders [42]. A recent study by Cedamon et al. [43] from Nepal's mid-hills also reinforces our findings. They argue that the emerging remittance economy of the country has increased the outmigration of Nepalese youths resulting in a short supply of labor force, which made the Nepalese farmers practice less labor-intensive cultivation practice such as agroforestry.

The results show that landholding size was the most influencing factor to determine the adoption of agroforestry. The likelihood of shifting from CAS to agroforestry practices increases with the size of landholdings. This may be because large holding farmers may prefer to increase their investments in new land management practices such as agroforestry since they can take risks and wait for the returns [44]. Besides, large holdings can be translated as an opportunity to new practices [45]. Having a private source of irrigation is positively associated with the farmers' decision of AFS adoption over conventional agriculture. A similar result was found in a study carried out in Himachal, India by Sood and Mitchell [46] and in Burkina Faso by Ayuk [47].

The results also suggest that off-farm-based households are likely to adopt the tree-based farming system such as AFS compared to their neighbors with farm-based livelihoods. The reason may be that the off-farm income helps farmers take a risk as it may serve as a safety net in case of crop failure resulting from sudden natural calamities and other unexpected events. Adopting a tree-based farming practice, therefore, may not be an attractive option to those families who require immediate returns, as farmers have to wait a long time to harvest trees. Until the tree crop harvest, farmers have to take a considerable loss in agriculture production from the time of establishment, which a subsistence farmer can hardly be able to cover the loss. Similar results were found in the Gunnungkidul region, Indonesia that the households with off-farm income sources are in a tree raising practice than those with farm-based households [8].

Similarly, 'livestock herd size' was found to positively influence a farmer's decision about adopting the tree-based farming system. It suggests that an increase in livestock herd size results in the increased likelihood of adopting AFS. In Nepal, trees are grown in the farmland for fodder, fuelwood and timber. Fodder is a good source of livestock feed in the study area. Trees provide green fodder during the dry season of the year, which is very important for the milking livestock to maintain milk production throughout the year. Table 2 reports that the tree densities and livestock herd size of the farming systems are statistically different. AFS farmers raised a higher number of trees and larger livestock herd compared to the ACS farmers. In the mid-hills of Nepal, the number of livestock was the most significant determinant of agroforestry adoption [41]. 
Extension service has also positive impacts on adopting tree-based farming systems. The AFS adoption rate increases with the number of extension services. In general, extension workers provide information to farmers and help to clarify the doubts that the farmers may have. They motivate farmers and increase their confidence to adopt to new practices. This finding corroborates the existing literature [39,49-51].

In addition, the proximity to the government-managed forests also determines the adoption of tree-based practices. The results indicate the likelihood of adopting tree-based farming systems increases with the distance to forests. When farmers easily get their daily needs of fuelwood, fodder, timber and food fulfilled from the nearby forest, they are reluctant to tree planting on their farmland [52]. On the contrary, the distant farmers have to spend more time in the collection of these products from the forest and therefore they are inclined to tree planting on their farms.

\section{Conclusions}

The results of this study suggest that agroforestry practice could be an appropriate strategy in the context of changing climate and economy in the farm-based economy. First, an agroforestry practice demands less labor compared to conventional agriculture practice. Adopting agroforestry may help to maintain the rural economy since the young population is out-migrating and the rural area is facing a short supply of labor. Besides, the agroforestry system is preferred by households having an off-farm income source. This suits the existing rural context as rural economy is in the transition towards monetized transactions due to outmigration for employment.

Agroforestry is a good source of fuelwood and fodder for livestock. Livestock raising is an integral part of Nepalese farming. The general assumption is that the farmers who live far from the forest tend to raise trees on their farmlands. Our finding reinforced this assumption. The reason for the distant farmers tending towards agroforestry adoption is that they would otherwise have to allocate a huge amount of time mostly every day for fuelwood and fodder collection from the forest. Not only the time saving, it has also contributed to forest conservation by reducing pressure on the forest.

The results also suggest that agroforestry is not a favorable option for smallholders as it is more likely to be adopted by large farmers. Collective farming through a cooperative approach might be a positive and practical step to engage smallholders in agroforestry promotion. As agroforestry gained attention in the international climate change policy, it could be an attractive option as a part of the mitigation strategy. The study clearly indicates that access to information may contribute to promote agroforestry practice, which requires intensive extension services.

Author Contributions: A.D., Conceptualization, formal analysis, and original draft preparation; R.K.R., review and editing, and inputs in methodological section.

Acknowledgments: We acknowledge the financial contribution from the Nepal Agroforestry Foundation (NAF) to carry out this research. The staff of Terai Private Forest Development Association (TPFDA) are also acknowledged for their support during data collection. The authors extend thanks to Mr. Nawa Raj Chapagain who helped produce the study area map. We appreciate the reviewers' comments and suggestions.

Conflicts of Interest: There are no conflicts of interest. 


\section{References}

1. Kotiaho, J. S.; Halme, P. The IPBES Assessment Report on Land Degradation and Restoration; IPBES Secretariat, UN Campus, Bonn, Germany, 2018.

2. Bai, Z. G.; Dent, D. L.; Olsson, L.; Schaepman, M. E. Proxy global assessment of land degradation. Soil Use Manage. 2008, 24(3), 223-234. doi: 10.1111/j.1475-2743.2008.00169.x

3. Nachtergaele, F.; Biancalani, R.; Petri, M. Land degradation: SOLAW background thematic report 3; Food and Agriculture Organization of the United Nations, Rome, Italy, 2011.

4. Conacher, A. Land degradation: A global perspective. N. Z. Geog. 2009,65(2), 91-94. doi: 10.1111/j.1745-7939.2009.01151.x

5. Alexandratos, N.; Bruinsma, J. World agriculture towards 2030/2050: the 2012 revision; Food and Agriculture Organization of the United Nations, Rome, Italy, 2012.

6. Jaquet, S.; Schwilch, G.; Hartung-Hofmann, F.; Adhikari, A.; Sudmeier-Rieux, K.; Shrestha, G.; Kohler, T. Does outmigration lead to land degradation? Labor shortage and land management in a western Nepal watershed. Appl. Geogr. 2015, 62, 157-170. doi: 10.1016/j.apgeog.2015.04.013

7. Rasul, G.; Thapa, G. B. Shifting cultivation in the mountains of South and Southeast Asia: regional patterns and factors influencing the change. Land Degrad. Dev. 2003, 14(5), 495-508. doi: 10.1002/ldr.570

8. Westarp, S. V.; Sandra Brown, H. S.; Shah, P. B. (2004). Agricultural intensification and the impacts on soil fertility in the Middle Mountains of Nepal. Can. J. Soil Sci. 2004, 84(3), 323-332. doi: 10.4141/S03-053

9. Jose, S. Agroforestry for ecosystem services and environmental benefits: an overview. Agrofor. Syst. 2009, 76(1), 1-10. doi:10.1007/s10457-009-9229-7

10. Nair, P. K.; Mohan Kumar, B.; Nair, V. D. Agroforestry as a strategy for carbon sequestration. J. Plant Nutr. Soil Sci. 2009, 172(1), 10-23. doi: 10.1002/jpln.200800030

11. Dhakal, A; Cockfield, G; Maraseni, T. N. Evolution of agroforestry-based farming systems: a study of Dhanusha District, Nepal. Agrofor. Syst. 2012, 86(1), 17-33. doi:10.1007/s10457-012-9504-x

12. Harvey, C. A.; Gonzalez, J.; Somarriba, E. Dung beetle and terrestrial mammal diversity in forests, indigenous agroforestry systems and plantain monocultures in Talamanca, Costa Rica. Biodivers. Conserv. 2006, 15(2), 555-585. doi:10.1007/s10531-005-2088-2

13. Kabir, M. E.; Webb, E. L. Can home gardens conserve biodiversity in Bangladesh?. Biotropica 2008, 40(1), 95-103. doi: 10.1111/j.1744-7429.2007.00346.x

14. Moguel, P.; Toledo, V. M. Biodiversity conservation in traditional coffee systems of Mexico. Conserv. Biol. 1999, 13(1), 11-21. doi: 10.1046/j.1523-1739.1999.97153.x

15. Neupane, R. P.; Thapa, G. B. Impact of agroforestry intervention on soil fertility and farm income under the subsistence farming system of the middle hills, Nepal. Agric. Ecosyst. Environ. 2001, 84(2), 157-167. doi: 10.1016/S0167-8809(00)00203-6

16. Dhakal, A. Evolution, Adoption and Economic Evaluation of an Agroforestry-based fFrming System with and without Carbon Values: The Case of Nepal. PhD dissertation, University of Southern Queensland, Australia, 2013.

17. Schwab, N.; Schickhoff, U; Fischer, E. Transition to agroforestry significantly improves soil quality: A case study in the central mid-hills of Nepal. Agric. Ecosyst. Environ. 2015, 205, 57-69. doi: 10.1016/j.agee.2015.03.004

18. Acharya, A. K.; Kafle, N. Land degradation issues in Nepal and its management through agroforestry. J. of Agric. Environ. 2009, 10, 133-143. doi: 10.3126/aej.v10i0.2138

19. Cockfield, G.J. Evaluating a Markets-based Incentive Scheme for Farm Forestry: A Case Study. PhD dissertation, University of Queensland, Australia, 2005.

20. Mercer, D. E. Adoption of agroforestry innovations in the tropics: a review. Agrofor. Syst. 2004, 61(1-3), 311-328. doi:10.1023/B:AGFO.0000029007.85754.70

21. Mbow, C.; Smith, P.; Skole, D.; Duguma, L.; Bustamante, M. Achieving mitigation and adaptation to climate change through sustainable agroforestry practices in Africa. Curr. Opinion Environ. Sustainability 2014, 6, 8-14. doi:10.1016/j.cosust.2013.09.002

22. Tscharntke, T.; Milder, J. C.; Schroth, G.; Clough, Y.; DeClerck, F; Waldron, A.; Ghazoul, J. Conserving biodiversity through certification of tropical agroforestry crops at local and landscape scales. Conserv. Lett. 2015, 8(1), 14-23. doi: 10.1111/conl.12110

23. Waldron, A.; Garrity, D.; Malhi, Y.; Girardin, C.; Miller, D. C.; Seddon, N. Agroforestry can enhance food security while meeting other sustainable development goals. Trop. Conserv. Sci. 2017, 10, 1-6. doi: $10.1177 / 1940082917720667$ 
24. Dhakal, A.; Cockfield, G.; Maraseni, T. N. (2015). Deriving an index of adoption rate and assessing factors affecting adoption of an agroforestry-based farming system in Dhanusha District, Nepal. Agrofor. Syst. 2015, 89(4), 645-661. doi: 10.1007/s10457-015-9802-1

25. Central Bureau of Statistics (2012). Environment Statistics of Nepal; Central Bureau of Statistics, Kathmandu, Nepal, 2012.

26. Kropko, J. Choosing between multinomial logit and multinomial probit models for analysis of unordered choice data. Master thesis, University of North Carolina, USA, 2008. doi: 10.17615/wz24-qq92

27. Miheretu, B. A.; Yimer, A. A. Determinants of farmers' adoption of land management practices in Gelana sub-watershed of Northern highlands of Ethiopia. Ecol. Process. 2017,6(1), 19-30. doi:10.1186/s13717-017-0085-5

28. Lin, Y.; Deng, X.; Li, X.; Ma, E. Comparison of multinomial logistic regression and logistic regression: which is more efficient in allocating land use?. Front. Earth Sci. 2014,8(4), 512-523. doi:10.1007/s11707-014-0426-y

29. Luus, F. P.; Salmon, B. P.; Van den Bergh, F.; Maharaj, B. T. J. Multiview deep learning for land-use classification. IEEE Geosci. Remote Sens. Lett. 2015, 12(12), 2448-2452. doi: 10.1109/LGRS.2015.2483680

30. Paton, L.; Troffaes, M. C.; Boatman, N.; Hussein, M.; Hart, A. Multinomial logistic regression on Markov chains for crop rotation modelling. In Information Processing and Management of Uncertainty in Knowledge-Based Systems (pp. 476-485), Proceedings-III of the 15th International Conference, Montpellier, France, July 15-19, 2014; Laurent, A., Strauss, O., Bouchon-Meunier, B., Yager, R. R., Eds.; Springer International Publishing, Switzerland. doi:10.1007/978-3-319-08852-5-49

31. Greene, W. H. Econometric Analysis, $5^{\text {th }}$ Ed.; Pearson Education: India, 2003; pp. 67-185.

32. Cheng, S.; Long, J. S. Testing for IIA in the multinomial logit model. Sociol. Methods Res. 2007, 35(4), 583-600. doi: 10.1177/0049124106292361

33. Alavalapati, J. R. R.; Luckert, M. K.; Gill, D. S. Adoption of agroforestry practices: a case study from Andhra Pradesh, India. Agrofor. Syst. 1995, 32(1), 1-14. doi: 10.1007/BF00713844

34. Anley, Y.; Bogale, A.; Haile-Gabriel, A. Adoption decision and use intensity of soil and water conservation measures by smallholder subsistence farmers in Dedo district, Western Ethiopia. Land Degrad. Dev 2007, 18(3), 289-302. doi: 10.1002/ldr.775

35. Carlson, J. E.; Schnabel, B.; Beus, C. E.; Dillman, D. A. Changes in the soil conservation attitudes and behaviors of farmers in the Palouse and Camas prairies: 1976-1990. J. Soil Water Conserv. 1994, 49(5), 493-500.

36. Thangata, P. H.; Alavalapati, J. R. Agroforestry adoption in southern Malawi: the case of mixed intercropping of Gliricidia sepium and maize. Agric. Syst. 2003,78(1), 57-71. doi: 10.1016/S0308-521X(03)00032-5

37. Roberts, J. S.; Laughlin, J. E.; Wedell, D. H. Validity issues in the Likert and Thurstone approaches to attitude measurement. Educ. Psychol. Meas. 1999, 59(2), 211-233. doi: 10.1177/00131649921969811

38. Adesina, A. A.; Mbila, D.; Nkamleu, G. B.; Endamana, D. Econometric analysis of the determinants of adoption of alley farming by farmers in the forest zone of southwest Cameroon. Agric. Ecosyst. Environ. 2000, 80(3), 255-265. doi: 10.1016/S0167-8809(00)00152-3

39. Adesina, A. A.; Chianu, J. Determinants of farmers' adoption and adaptation of alley farming technology in Nigeria. Agrofor. Syst. 2002, 55(2), 99-112. doi: 10.1023/A:102055613

40. Fabiyi, Y. L.; Idowu, E. O.; Oguntade, A. E. Land tenure and management constraints to the adoption of alley farming by women in Oyo State of Nigeria. Nigerian J. Agric. Ext. 1991, 6(1/2), 40-46.

41. Neupane, R. P.; Sharma, K. R.; Thapa, G. B. Adoption of agroforestry in the hills of Nepal: a logistic regression analysis. Agric. Syst. 2002, 72(3), 177-196. doi: 10.1016/S0308-521X(01)00066-X

42. Rai, R. K.; Bhatta, L. D.; Acharya, U.; Bhatta, A. P. Assessing climate-resilient agriculture for smallholders. Environ. Dev. 2018, 27, 26-33. doi:10.1016/j.envdev.2018.06.002

43. Cedamon, E.; Nuberg, I.; Pandit, B. H.; Shrestha, K. K. Adaptation factors and futures of agroforestry systems in Nepal. Agrofor. Syst. 2018, 92(5), 1437-1453. doi:10.1007/s10457-017-0090-9

44. Amsalu, A.; De Graaff, J. Determinants of adoption and continued use of stone terraces for soil and water conservation in an Ethiopian highland watershed. Ecol. Econ. 2007,61(2-3), 294-302. doi: 10.1016/j.ecolecon.2006.01.014

45. Nowak, P. J. The adoption of agricultural conservation technologies: economic and diffusion explanations. Rural Sociol. 1987, 52(2), 208-220. 
46. Sood, K. K.; Mitchell, C. P. Identifying important biophysical and social determinants of on-farm tree growing in subsistence-based traditional agroforestry systems. Agrofor. Syst. 2009, 75(2), 175-187. doi: 10.1007/s10457-008-9180-z

47. Ayuk, E. T. Adoption of agroforestry technology: the case of live hedges in the Central Plateau of Burkina Faso. Agric. Syst. 1997, 54(2), 189-206.

48. Sabastian, G.; Kanowski, P.; Race, D.; Williams, E.; Roshetko, J. M. Household and farm attributes affecting adoption of smallholder timber management practices by tree growers in Gunungkidul region, Indonesia. Agrofor. Syst. 2014, 88(2), 257-268. doi: 10.1007/s10457-014-9673-x

49. Ison, R.; Ison, R. L.; Russell, D. Agricultural Extension and Rural Development: Breaking out of Knowledge Transfer Traditions; Cambridge University Press, Cambridge, UK, 2000; pp.52-77.

50. Lohr, L.; Park, T. Discrete/continuous choices in contingent valuation surveys: Soil conservation decisions in Michigan. Appl. Econ Perspect. P. 1994, 16(1), 1-15. doi: 10.2307/1349516

51. Paudel, G. S.; Thapa, G. B. Impact of social, institutional and ecological factors on land management practices in mountain watersheds of Nepal. Appl. Geogr. 2004,24(1), 35-55. doi: 10.1016/j.apgeog.2003.08.011

52. Rai, R. K.; Dhakal, A.; Khadayat, M. S.; Ranabhat, S. Is collaborative forest management in Nepal able to provide benefits to distantly located users?.Forest Policy Econ. 2017,83, 156-161. doi: 10.1016/j.forpol.2017.08.004 